Working Paper

Statistics and Econometrics Series 09-69 (20)

November 2009
Departamento de Estadística

Universidad Carlos III de Madrid

Calle Madrid, 126

28903 Getafe (Spain)

Fax (34) 91 624-98-49

\title{
RISK FACTORS IN OIL AND GAS INDUSTRY RETURNS: INTERNATIONAL EVIDENCE
}

\section{Sofia B. Ramos and Helena Veiga *}

\begin{abstract}
This paper analyzes the exposure of the oil and gas industry of 34 countries to oil prices. Using a multifactor panel model to estimate the oil and gas excess stock returns, our results strongly support the view that oil price is a globally priced factor for the oil industry. In particular, the response of the oil and gas sector to changes oil prices is positive and larger for developed countries than for emerging markets. The industry response is asymmetric, with positive oil price changes having a greater impact on the oil sector returns than negative changes. Furthermore, local market index returns, currency rates and oil price volatility also have a significant impact on oil industry's excess returns. Finally, industry local sensitivities seem to vary with stock market activity and with levels of appropriation of industry revenues by governments. Results are robust to a battery of tests.
\end{abstract}

Keywords: Multifactor asset pricing models; Panel Data; Oil industry

Sofia B. Ramos: ISCTE Business School, Avenida das Forças Armadas, 1600-083 Lisboa, Portugal. Email: sofia.ramos@iscte.pt. Corresponding author.

Helena Veiga: Departamento de Estadística, Universidad Carlos III de Madrid, C/ Madrid 126, 28903 Getafe (Madrid) and Finance Research Center, ISCTE Business School. Email:mhveiga@est-econ.uc3m.es 


\title{
Risk Factors in Oil and Gas Industry Returns: International Evidence *
}

\author{
Sofia B. Ramos ${ }^{\dagger} \quad$ Helena Veiga
}

First Version: October 2009

\begin{abstract}
This paper analyzes the exposure of the oil and gas industry of 34 countries to oil prices. Using a multifactor panel model to estimate the oil and gas excess stock returns, our results strongly support the view that oil price is a globally priced factor for the oil industry. In particular, the response of the oil and gas sector to changes oil prices is positive and larger for developed countries than for emerging markets. The industry response is asymmetric, with positive oil price changes having a greater impact on the oil sector returns than negative changes. Furthermore, local market index returns, currency rates and oil price volatility also have a significant impact on oil industry's excess returns. Finally, industry local sensitivities seem to vary with stock market activity and with levels of appropriation of industry revenues by governments. Results are robust to a battery of tests.
\end{abstract}

JEL classification: C23; G12; Q4; L72

Keywords: Multifactor asset pricing models; Panel Data; Oil industry

${ }^{*}$ The authors acknowledge financial support from Financial Research Center/UNIDE, from the Spanish Ministry of Education and Science, research project SEJ2006-03919 and European Union, research project EU-FP7SSH-2007-1.

†ISCTE Business School, Avenida das Forças Armadas, 1600-083 Lisboa, Portugal. Email: sofia.ramos@iscte.pt. Corresponding author.

‡Statistics Department, Universidad Carlos III de Madrid, C/ Madrid 126, 28903 Getafe, Spain. ISCTE Business School, Avenida das Forças Armadas, 1600-083 Lisboa, Portugal. 


\section{Introduction}

The world dependence on energy has been growing steadily over the last decades. Thriving economies such as China and India are quickly becoming large oil consumers. From instance, China has doubled its consumption from 1996 to 2006. Moreover, major oil exporting countries are rapidly developing and countries that used to be net exporters, e.g. Indonesia, are now net importers. Not surprisingly, the potential returns of oil and related activities have drawn the attention of the financial community, and the financial investment related with oil has gained importance in the world's financial markets. As shown in Figure 1, the number of mutual funds and exchange traded funds that invest in oil and in energy companies has steadily increase in recent years. According to LIPPER Hindsight, in 2008 there were 379 funds mutual funds and 26 exchange traded funds that had the FTSE Oil\&Gas Industry Index as benchmark. These funds are likely to invest in companies from several countries and it is of the utmost importance for them to control the risk of such investments.

The dependence of global growth on energy is at the center of the international agenda, raising the question of whether the globalization of economies has contributed to the emergence of global risk factors as a source of variation in international stock returns to centre stage. In the academic literature, Chen et al. (1986) are among the first to study oil prices as a potential source of risk in U.S. stock markets. Ferson and Harvey (1994a) and Ferson and Harvey (1994b) examine whether changes in oil prices are a source of global risk in different national markets. Huang et al. (1996) examine the relationship between daily oil futures returns and daily U.S. stock returns. Jones and Kaul (1996) and more recently Driesprong et al. (2008) investigate the predictive power of oil price changes in stock markets.

However, there is no conclusive evidence that oil is an important factor for financial markets. On one hand, Huang et al. (1996), Chen et al. (1986) and Ferson and Harvey (1994b) find that

oil futures returns do not have much impact on the broad-based market indices such as the S\&P 500 and that there is no reward for oil price risk in stock markets, respectively. On the other hand, Jones and Kaul (1996) provide evidence that aggregate stock market returns in the U.S., 
Canada, Japan and the U.K. are negatively sensitive to the adverse impact of oil price shocks on the economies and more recently, Driesprong et al. (2008) find some predictability power in oil returns.

This paper analyzes whether oil is a global source of investment risk. As argued by Albuquerque et al. (2005), one of the consequences of the increased integration of stock markets is the increased role of worldwide risks. Despite the growing interest of investors in global allocation, the empirical evidence does not provide a global picture of the importance of oil as a global risk factor. Up till now, most of the literature on the sensitivity of stock markets to changes in the oil price has been conducted on countries's stock returns or limited to industries where the country's economy is quite dependent on this natural resource (see Sadorsky, 2001; Boyer and Filion, 2007; Faff and Brailsford, 1999; Hammoudeh and Li, 2004). The only exceptions is Nandha and Faff (2008) that analyze a set of industries at global level. They find that oil prices rises have a detrimental effect on industry returns in all sectors except mining and oil and gas industries.

Our study examines whether the oil and gas industry has a factor exposure to oil price changes in a sample of 34 countries in the period from 1998 to 2009. The paper uses panel data modeling to test an international APT model. As argued by Ferson and Harvey (1994b), factor model regressions are useful to control the risk of international investments to global factors. The methodology allows the cross sectional and time series features of the data to be explored simultaneously.

We document the following results. First, the oil and gas industry around the world shows exposure to the oil factor. The industry also shows exposure to the world market portfolio, However, the exposure to the local market index is greater. This result is consistent with models of partial segmentation and with the argument of Carrieri et al. (2004) that country-level integration does not preclude industry-level segmentation. The oil and gas industry also shows some exposure to currency rates variations against the U.S. dollar and to oil price volatility. Industry returns increase with the appreciation of the local currency against the dollar and with the 
volatility of oil prices. Second, the results also show that exposure to oil exists in both developed and emerging markets. However, the sensitivity coefficient is larger for the industries in developed countries than in the emerging markets. Third, oil price changes have asymmetric effects on returns, the coefficient is statistically larger in prices surges than in price slides. Finally, testing for stability of the coefficients over time, we find that oil is priced in the two subperiods, but the sensitivity is larger in the most recent subperiod of 2002-2009. Results are also robust when we change the proxy for oil prices, the data frequency from monthly to weekly and to the inclusion of time dummies.

We also question whether the differences in exposures can be associated with some country specific features. We find that countries with greater sensitivities are associated with higher stock market activity and with better governance standards. More specifically more predatory governments, i.e. the likelihood that stockholders might be expropriated, diminish the sensitivity of industry returns.

The paper has the following structure: Section II describes the methodology and data. Section III describes the empirical results. First, we present the results of the baseline regression. Then, we disentangle differences on the sensitivity between industries in developed and in emerging markets, the existence of asymmetric shocks and finally the stability of the exposure over the time period. Section IV explores the reasons behind the different country sensitivities. Section $\mathrm{V}$ presents the robustness analysis and section VI concludes.

\section{Methodology and Data}

This section describes the methodology and the data used to make inferences on the importance of oil prices as a global factor. To estimate the factor exposure we use panel data methodology. 


\section{A. Methodology}

We follow the literature that uses the international APT models to examine the impacts of global factors on stock returns (see Ferson and Harvey, 1994b; Karolyi and Stulz, 2003). The model is as follows

$$
r_{i, t}=\alpha_{i}+\sum_{k=1}^{K} \beta_{k} F_{k, t}+u_{i, t}
$$

where $r_{i, t}$ is the excess return of oil and gas industry of country $i$ at time $t$. The $\alpha_{i}$ is the intercept. This means that the effect of a change in one explanatory variable is the same for all countries and all periods, but the average level for country $i$ may be different from that of country $j . \alpha_{i}$ thus captures the effects of those variables that are peculiar to the $i-t h$ country and that are constant over time. $\beta_{k}$ are the coefficients of $r_{i, t}$ on the $K$ risk factors, $F_{k, t}$ with $k=1, \ldots K$. The $u_{i, t}$ are the error terms and represent the 'non - systematic' excess returns relative to the factors. According to Ferson and Harvey (1994b) the factor model regressions provide information about the usefulness of global factors in controlling the risks of international investments.

Our choice of global risk factors follows previous theoretical and empirical work on international asset pricing. Like the models by Stulz (1981) and Adler and Dumas (1983), one of the factors will be the world market portfolio.

Partial segmentation models suggest that partial segmentation markets may be more appropriate for countries that have only recently experienced full liberalization of their capital markets or for emerging markets that have initiated the process of liberalization (see Errunza and Losq, 1985). These models suggest that both local and world factors should influence equilibrium asset returns. Therefore, given that our sample includes a broad range of countries we add a local market return as a factor.

The interest in using oil prices as a factor is not new. Works by Chen et al. (1986) and Ferson and Harvey (1994b) test oil prices exposures in a national and global investment setting, respectively. Accordingly, we add a 'oil factor' in the model specification.

Additionally, we test whether the oil industry shows some sensitivity to changes in currency 
rates against the U.S. dollar. Currency rate changes are one of the main risks in foreign international investments. The Solnik (1974) model advocates that exchange rate risks should be "priced" when purchasing power parity fails. Adler and Dumas (1983) also present theoretical support for exchange rate risks being priced in a global setting. On the empirical side, Dumas and Solnik (1995) and De Santis and Gerard (1998) find that currency risk is priced in a conditional setting for aggregate market returns. Given this evidence, we consider that exchange rate risk might be relevant in the context of the oil industry given that oil is priced in international markets in U.S. dollars.

The following equation describes this relation:

$$
O I L_{-} I N D_{i, t}=\alpha_{i}+\beta_{W O R L D} \cdot W O R L D_{t}+\beta_{L O C A L} \cdot L O C A L_{i, t}+\beta_{O I L} \cdot O I L_{t}+\beta_{C U R R} \cdot C U R R E N C Y_{i, t}+u_{i, t},
$$

where the dependent variable is the excess return of country $i$ oil and gas industry at time $t$ on a risk free rate $\left(O I L_{\_} I N D_{i, t}\right)$. The independent variables are the world market excess return on a risk free rate at time $t\left(W O R L D_{t}\right)$, the excess returns of the local market $i$ at time $t\left(L O C A L_{i, t}\right)$, the return of an oil price index at time $t\left(O I L_{t}\right)$ and the currency rate variations of country $i$ at time $t\left(C U R R E N C Y_{i, t}\right)$. Finally, $\alpha_{i}$ accounts for the possible heterogeneity among gas and oil industries and $u_{i, t}$ is the error term.

\section{B. Data}

We collect monthly returns for oil industry indexes based on Datastream industry classification. Datastream has recently adopted the Industry Classification Benchmark (ICB) as its standard classification tool across a range of its global data products and services. Oil \& Gas Industry returns correspond to Level 2 of ICB. Datastream indexes are weighted by market capitalization, and have an extensive coverage of each country's total market capitalization.

Due to data availability, our final sample covers 34 countries from May 1998 to June 2009, totalling 134 monthly observations. Returns are expressed in U.S. dollars and excess returns are computed using the one-month Eurodollar interest rate that is available from Datastream. The 
choice for U.S. dollars as the reference currency is justified by the fact that the price of oil is determined in U.S. dollars in international markets.

Table I reports the summary statistics for industry indexes by country. Most industries have positive excess returns during the period. Only ten out of 34 have negative excess returns. Volatility is smaller in U.S. and U.K. oil industries, $6.286 \%$ and $6.773 \%$ respectively and higher in countries like Denmark or Turkey, over 16\%. All industries, except the one from Japan, present high kurtosis values. We also observe that the distribution of excess returns of oil and gas industries is negatively skewed for the majority of the countries. Consequently, the assumption of Gaussian returns is rejected by the Jarque-Bera test for almost all countries.

The factors are the following financial variables: the market portfolio that we compute using the logarithm changes of the world market portfolio index (WORLD) and the logarithm changes of the local market portfolio excess returns $(L O C A L)$. Both returns are in excess of a short term interest rate, the one-month Eurodollar interest rate (see Ferson and Harvey, 1994a).

The oil factor is proxied by the logarithm difference of oil prices $(O I L)$. We collect several sources of oil prices but since the correlation among them is quite high, around 0.95, we decide to use the price index of London Brent Crude Oil priced in U\$/BBL in the main analysis. ${ }^{1}$ Brent crude is sourced from the North Sea. It is used to price two thirds of the world's internationally traded crude oil supplies, and is a benchmark for the oil production from regions such as Europe, Africa and the Middle East.

$C U R R E N C Y$ is the logarithm changes in currency rates against the U.S. dollar. Given that all bilateral rates are expressed in U.S. dollars by unit of the foreign currency, a positive change in the rate means an appreciation of the foreign currency with respect to U.S. dollars.

To complement the analysis we also analyze the exposure to oil volatility. VOL_OIL is the oil

\footnotetext{
${ }^{1}$ The other oil prices used were the Crude Oil-Brent Cur. Month FOB U\$/BBL, the S\&P GSCI Crude Oil Spot-Price Index. In the robusteness analysis we will present the results using the NYMEX Light Crude Oil Continous Settlement Price -U\$/BBL.
} 
volatility obtained directly from the data by applying a moving average to the squared residuals,

$$
V O L \_O I L=\left[(m+1)^{-1} \sum_{j=0}^{m} \hat{\epsilon}_{t-j}^{2}\right]^{0.5}
$$

with $t=0, \ldots, n-m-1$ and $m=4$, obtaining by fitting an $\mathrm{AR}(1)$ model to oil returns, $O I L_{t}=c+\phi_{1} O I L_{t-1}+\epsilon_{t}$ (see Gallant and Tauchen, 1998). This method of estimation is typically used when the first two conditional moments are evaluated (see Bansal and Zhou, 2002; Durham, 2003; Doran and Ronn, 2008).

The complete model is given by

$$
\begin{aligned}
\text { OIL_IND } D_{i, t}= & \alpha_{i}+\beta_{W O R L D} \cdot W O R L D_{t}+\beta_{L O C A L} \cdot L O C A L_{i, t}+ \\
& \beta_{O I L} \cdot O I L_{t}+\beta_{V O L \_O I L} \cdot V O L \_O I L_{t}+\beta_{C U R R} \cdot C U R R E N C Y_{i, t}+u_{i, t} .
\end{aligned}
$$

Figure 2 depicts the oil price index over the sample time period. The price of oil does not fluctuate very much till around 2002. However, oil prices passed \$50/BBL in 2005, 100\$/BBL in 2007 and almost \$150/ BBL in July 2008. As many countries have entered economic recession, prices have continued to slide until the end of 2008, to increase again during 2009. The value in June 2009 was again close to $\$ 70 /$ BBL. The graph below depicts the variations in oil prices. Many large monthly variations are visible, surpassing the barrier of $+/-10 \%$. There are four large decreases in prices that correspond to December 2000, March 2003 and more recently to October and December 2008. On the other hand, prices spikes can be observed in March 1999, May 2000, March 2002, January 2005 and May 2009.

Table II presents the descriptive statistics of the independent variables and they are worthy of a brief comment. First, both the world and most local market returns register negative excess returns in the period. For the latter, the standard deviation ranges from $4.915 \%$ for the U.S. to $16.421 \%$ for Turkey. The kurtosis is higher than three in all countries, except Japan, and the distributions of local market returns are negatively skewed. Regarding the variable $O I L$, we observe that its mean in the period is $1.178 \%$ per month and registers high volatility. Finally, 
the descriptive statistics on the currency rates show that most of the currencies have appreciated against the U.S. dollar and the volatility is higher for those of Brazil and Argentina, whose values are over $6 \%$. Overall, we observe that the exchange rate variability is lower on average compared to the volatility of industry returns. Since kurtosis is higher than three and there is negative skewness, the Jarque-Bera test lead us to reject the null of Gaussian returns.

Finally, Table III presents the correlation among independent variables. There could be concerns that local market returns and currency could present high correlation as sometimes they are driven by the same variables. However, it does not seem the case for our sample.

\section{Estimation}

Due to the structure of data, equations (2) and (3) will be estimated as a panel. One of the advantages of this approach is that it enhances the quality and quantity of data and allows the study of the dynamics of the variable of interest with relative short time series. Moreover, the intercepts can differ according to the country for capturing the cross section heterogeneity. In this context, we estimate a fixed effects panel with robust standard errors. The advantage of these models is that it can account for the fact that the error terms may be correlated with the country effects.

We can also assume that the constant term is a function of a mean value plus a random error that should be uncorrelated with the regressors. This random error is heterogeneity specific to a country and it must not be correlated with the regressors. If this is the case, the random effects specification may be more powerful and parsimonious. We estimate the random effects model using the GLS estimation method and we test the correlation between the random error and the regressors with the Hausman test, whose null hypothesis, $H_{0}$, is the nonexistence of correlation. We perform the Hausman test for all specifications with the results that we cannot reject the hypothesis of no correlation at any significance level in all cases.

Subsequently, in the robustness section, we extend the fixed effects and random effects models by allowing for temporal effects. All the models are estimated using STATA 9 software. 


\section{Empirical Results}

This section describes the results. First, we present the results of the baseline case. Second, we disentangle differences on the sensitivity to oil between developed and emerging markets and then, we test whether oil shocks have asymmetric impacts on the excess returns of the oil and gas sector. Finally, we check whether the sensibilities are constant over the time period.

\section{A. Regression Results}

Table IV presents the estimation results of equations (2) and (3). Panel A shows the fixed effects estimations while Panel B presents the random effects estimation results. Since both estimations are quite similar, we will addressed them together. Model (1) corresponds to the international CAPM as industry returns are regressed against the world market portfolio. The coefficient is around one and statistically significant and the R-squared is around 0.25 . Therefore, we cannot reject the validity of the international CAPM.

Model (2) adds the local market returns as an extra explanatory variable. Including both world and local market portfolios on the regression, turns out that the coefficient of WORLD is no longer statistically significant while LOCAL is statistically significant at standard levels of confidence. The $R^{2}$ increases substantially to around 0.56 . This seems to suggest that although the world portfolio has some explanatory power, the sensitivity to the local market is stronger, which is consistent with the models of partial segmentation. The finding that world market returns are not priced is not completely surprising. Ferson and Harvey (1994b) also find that the world market betas provide a poor explanation of the average returns across countries and Stulz (1981) and Adler and Dumas (1983) state the validity of the model only in a setting with no exchange rate risk and a constant opportunity set. This result is still valid in the successive regressions. Hence, hereafter we opt to show only the results with the local market portfolio for sake of brevity. ${ }^{2}$

Models (3) to (5) include already the variable OIL. The coefficient of this variable is always

\footnotetext{
${ }^{2}$ Results are available from the authors upon request.
} 
statistically significant and positive, indicating that the returns of the oil and gas sector respond positively to oil price increases and negatively to oil price decreases. CURRENCY and VOL_OIL are added in the model in turn and seem to be priced factors with a positive coefficient. This suggests that the market responds positively to appreciations of the local currency against the dollar and to the increase of oil volatility. The last estimation (model (5)), makes a horse race with all variables and the results show that all variables are still statistically significant. Overall, the R-squared of the models are quite high with values of around 0.57.

Comparing the adequacy of models, the Hausman test suggests that the random effects specifications are more appropriate than the fixed effects models since we do not reject the null hypothesis of no correlation between the errors of the models and the regressors. For instance, using model (3) and monthly data, the value of the Hausman statistic is 3.26 with p-value of 0.5157 .

Therefore, monthly oil price changes are found to have a significantly positive impact on monthly returns of the oil and gas industry around the world and are a significant risk factor for international investments in this sector.

\section{B. Developed Countries vs. Emerging Markets}

It is frequently discussed in the literature that emerging markets might not be fully integrated in the economy since they show some different asset pricing behavior. For instance, Carrieri and Majerbi (2006) advocates that the empirical evidence suggests that expected returns of emerging markets are more likely to be affected by local than global risk factors.

To discern whether there is a difference among industries belonging to developed and emerging markets, we divided our sample and reran equations (2) and (3). Table V presents the results distinguishing developed countries (Panel A) from emerging countries (Panel B). First, we observe that both subsamples show a high level of sensitivity to local markets. Second, the OIL variable is a priced factor, but the coefficient of OIL is larger in the developed countries sample than in the emerging markets sample. Nevertheless, the changes in currency rates against the U.S. 
dollar are not priced in the developed countries sample, only the oil volatility is priced. On the other hand, for emerging markets, currency variations are a priced factor at standard levels of confidence which is consistent with the results of Carrieri and Majerbi (2006), but oil volatility is not statistically significant.

To gauge whether the differences in sensitivities of oil are statistically different, we test the null that coefficients are equal in the country subsamples, which is rejected at standard levels of confidence. $^{3}$ Therefore, we find evidence that OIL is a global factor, but the exposure is greater in developed countries industries than in emerging markets industries.

\section{Asymmetric Effects of Oil Price changes}

Some literature demonstrates that the impact of oil price changes on the macroeconomy is asymmetric, i.e., oil price hikes have a negative impact on GDP, but that falls in oil prices do not necessarily lead to a positive impact on output and not of the same degree (see Mork, 1997; Mork et al., 1994). Accordingly, we would like to determine whether the asymmetric effects on economic output also translate into industry returns. To this end, we implement the following model:

$$
\begin{aligned}
\text { OIL_IND } D_{i, t}= & \alpha_{i}+\beta_{W O R L D} \cdot W O R L D_{t}+\beta_{L O C A L} \cdot L O C A L_{i, t}+\beta_{O I L P} \cdot D \cdot O I L_{t}+ \\
& \beta_{O I L N} \cdot(1-D) \cdot O I L_{t}+\beta_{V O L \_O I L} \cdot V O L_{-} O I L_{t}+\beta_{C U R R} \cdot C U R R E N C Y_{i, t}+u_{i, t},
\end{aligned}
$$

where $D$ is a dummy variable that takes a value of one if the change in the oil price is positive and zero if it is negative; $\beta_{O I L P}$ and $\beta_{O I L N}$ are coefficients corresponding to up and down movements in the oil returns, respectively. All the remaining items have the same meaning those described for equation (2).

Table VI contains the results of the estimation using fixed effects (Panel A) and random effects (Panel B). Some comments are worthy of note. First, the LOCAL variable has a statistically significant coefficient as in the previous estimations. Secondly, the sensitivity to oil is again

\footnotetext{
${ }^{3}$ The results are not presented but are available from authors upon request.
} 
positive and statistically significant, however the coefficient is higher when price changes are positive than when they are negative. Therefore, the results confirm the hypothesis of the existence of asymmetry. Third, CURRENCY is statistically significant both in fixed and random effects specifications. Fourth, the volatility of oil price does not affect industry returns.

To conclude about the statistical significance of this finding, we formally test for asymmetric responses of oil and gas industry excess returns to oil price shocks. The first test analyzes the null hypothesis of no asymmetry $\left(H_{0}: \beta_{O I L P}=\beta_{O I L N}\right)$. The null is rejected at standard levels of confidence for model (1) and rejected at 10\% confidence level for the remaining models. Therefore, the coefficient tends to be larger for price surges than for price slides.

The second test analyzes the joint hypothesis that both coefficients are equal to zero $\left(H_{0}\right.$ : $\beta_{O I L P}=0$ and $\beta_{O I L N}=0$ ). If there is no asymmetry and no sensitivity to oil, the coefficient should be jointly equal to zero. The hypothesis that both coefficients are equal to zero is always rejected. Our results contrast with the evidence provided by Nandha and Faff (2008) that find little evidence of asymmetry, but we recall that they analyze industries at global levl.

\section{Subperiods}

As shown in Figure 2, the price of oil follows different patterns during the sample period, which makes us question a possible structural change in the sensitivity of oil and gas excess returns to oil prices over the sample.

Table VII reports the estimation results for two subsamples. The first subsample corresponds to the period 1998-2001 (Panel A) and the second subsample corresponds to the period 2002-2009 (Panel B). We test our assumption on the random effects specification since the Hausman tests suggest that they is no correlation between the heterogeneity effect and the regressors. For both subsamples, the LOCAL and OIL variables are statistically significant factors. However, the coefficient of OIL is slightly higher in the period 2002-2009. The major differences came from the CURRENCY variable which is priced in the first subperiod but not in the latter period. Moreover, the oil volatility is priced in both subsamples but its coefficient is of less magnitude in 
the second part of the sample. Therefore, the results suggest no differences in the impact of oil prices. We test the null of equal oil returns coefficients in both subperiods and we only reject the null hypothesis for a $10 \%$ confidence level. Finally, we also obtain statistical support that the decrease in the impact of oil volatility is statistically significant at standard levels of confidence.

\section{Explaining Exposures to oil prices}

As shown in the previous section, the oil and gas industry shows some exposure to oil prices, though with some differences between developed and emerging markets. In this section we try to understand what might explain the difference of the sensitivities of the countries to oil prices. To do this, we relate the sensitivities with structural features of the markets.

The first variable we analyze is associated with the quality and the disclosure of accounting standards. If firm information is not trustworthy or clear, market participants might not show any reaction to it. Accounting standards are proxied by the CIFAR index $(C I F A R)$, from the Center for Financial Analysis and Research, which assess information on comprehensiveness and quality of the companies' balance sheets and income statements. The maximum value of the index is 90 and the minimum is 0 .

We next analyze the extent to which a government's respect for private property rights affects sensitivities. As shown by Durnev and Guriev (2007), industries whose profits are correlated with oil prices are more vulnerable to expropriation. Therefore, potential higher profits do not lead necessarily to more value for shareholders; on the contrary, it can increase the likelihood of expropriation, and thus the firm value does not increase. We use the sum of three indexes from La Porta et al. (1998) and construct a good governance index (GOOD_GOV) (see e.g. Morck et al., 2000). These indexes measure (1) government corruption, (2) the risk of expropriation of private property by the government, and (3) the risk of government repudiation of the contracts. Higher values indicate that there is more respect for private property.

We also use a measure associated with the quality of institutions, the KKZ Composite Index 
(KKZ_INDEX); this index was developed by Kaufman et al. (1999) and has been used in the literature (e.g. Beck et al., 2006) to measure the overall level of institutional development. It is composed of the following items: voice and accountability, government effectiveness, political instability, regulatory quality, rule of law and control of corruption. Data are available from the year 2000 and higher values are associated with better quality of institutions. ${ }^{4}$

Finally, we relate the response of investors to stock market activity. Active stock markets are likely to incorporate news faster and be more informationally efficient. To measure stock market activity we use the weight of stock market trade over GDP (SMT/GDP) from the world database of the World Bank (see Beck et al., 2000). Table A.1 in the appendix displays the values of the variables for the sample countries.

The analysis will be conducted in two steps. In the first step, we run a SUR regression ${ }^{5}$ to obtain $\beta_{O I L, i}$ the sensitivity of the OIL\&GAS industry of country $i$ to oil prices. The SUR regression is run using two specifications to give the results robustness: the first using LOCAL and OIL as explanatory variables; the second using LOCAL, OIL and CURRENCY. In the second step, we run a cross sectional regression where $\beta_{O I L, i}$ is the dependent variable and the independent variables are the above mentioned variables. The paucity of observations is a limitation of the second step and we are therefore careful and parsimonious in the inclusion of explanatory variables.

Results are displayed on table VIII. Panel A displays the results of the second regression where $\beta_{O I L, i}$ come from the regression where LOCAL and OIL are explanatory variables and Panel B displays the results of the second regression where $\beta_{O I L, i}$ come from the regression where LOCAL, OIL and CURRENCY are explanatory variables. Models (1)- (4) are univariate regressions. The table displays the coefficients and the White-consistent standard errors for the two models. As results are quite similar we will comment on them together. The coefficients of SMT/GDP and GOOD_GOV are statistically significant at standard levels of significance, and CIFAR is only at $10 \%$ confidence levels for Panel A. Models (5) -(7) simultaneously test several variables. The

\footnotetext{
${ }^{4}$ See the Worldwide Governance Indicators (WGI) project of the World Bank.

${ }^{5}$ We also did OLS estimation and results remain pratically unchanged.
} 
coefficient of SMT/GDP is positive and indicates that more active stock markets are associated with larger market responses to changes in oil prices. Governance indicators also have a positive coefficient, above all the coefficient associated with good governance of the governments. This is in line with the idea that natural resources are under the scrutiny of governments. However, the quality of the institutions of the country has a positive effect on sensitivity to oil changes, it is not statistically significant. The last model (7) also tests the importance of the quality of accounting information, but it is not statistically significant.

Therefore, our results find evidence that the exposure of the industry returns to oil prices is larger in more active stock markets and where governments are likely to be less predatory.

\section{Robustness Analysis}

The robustness of the results is checked in different ways. A first concern is that our results might be dependent on the type of variable that we use for proxyng the oil factor. With the purpose of checking this, we reran equations (2) and (3) using the NYMEX-Light Crude Oil Continuos - Settlement Price - U\$/BBL. This price is for the settlement of the NYMEX future contract, which is the most widely traded future contract and it is also used as the benchmark to set oil-product related prices. As seen in Table IX results remain unchanged.

Next, we estimate an augmented version of the original panel by allowing the intercepts to vary over time. We introduce $t-1$ time dummies with the intention of catching possible shifts in the level of the oil and gas industry's excess returns. We perform a joint significant test of the time dummy variables and we reject the null hypothesis that they are jointly statistically insignificant at a 5\% significance level. Table X shows the estimation results of equations (2) and (3) with time dummies. The coefficient of OIL is still statistically significant, but CURRENCY and VOL_OIL are no longer priced factors.

A third concern is that our results might depend on the data frequency. Therefore, we repeat the estimations using weekly observations. Table XI reports the results of these estimations. For 
this frequency, the world factor is still statistically significant in the presence of the local factor, although the sensitivity to local market returns is higher. The OIL and CURRENCY variables are statistically significant, but VOL_OIL is not.

Overall, results on the importance of oil prices for the oil and gas industry kept unchanged.

\section{Conclusion}

Understanding the behavior of equity returns is a key issue in finance research. Researchers have long been trying to understand the factors that impact the equity returns of companies and markets. This paper focuses on whether oil price is a global factor and contributes to the literature by studying the exposure of the oil and gas industry to a set of factors.

Despite the general evidence of the negative impact of oil prices on the economy (see Hamilton, 1983; Jones et al., 2004), we find that it has a positive impact on the market returns of the oil and gas industry around the world. In particular, the response of the oil and gas sector to changes in oil prices is positive and larger for developed countries than for emerging markets. Positive oil price changes have a larger impact on the oil sector returns than negative changes, suggesting asymmetry of responses. Furthermore, local market indices returns, currency rate variations and oil price volatility also have a significant impact on the oil industry's excess returns.

The positive exposure might be interpreted as the market understanding that these firms have the ability to pass their oil sensitivity to customers through prices changes, the possible existence of effective hedging against oil price risk or even the fact that oil price risk cannot be diversified away in the spirit of some international asset pricing models (see Stulz, 1981; Hodrick, 1981; Solnik, 1993). A second striking aspect is that this industry is strongly affected by the local markets returns, although companies operate their business in several countries.

Cross-sectional variability in exposures is consistent with the idea that increases in oil prices create higher revenues for companies, that might be appropriated by other parties that are not stockholders, e.g. governments. Another alternative interpretation for this result is that although 
oil price surges lead to revenue increases, governments with low standards of governance might be a hindrance to firm growth.

Our paper has direct implications for the financial community that invests in the oil and gas industry. We have identified several sources of variation of industry returns which are useful for controlling international risks of investments in this sector. Moreover, it also suggests that common investors can hedge their wealth against oil price increases by investing in these firms.

\section{References}

Adler, M. and B. Dumas (1983). International Portfolio Selection and Corporation Finance: A synthesis. Journal of Finance 46, 925-984.

Albuquerque, R., N. Loayza, and L. Serven (2005). World market integration through the lens of foreign direct investors. Journal of International Economics 66(2), 267-295.

Bansal, R. and H. Zhou (2002). Term structure of interest rates with regime shifts. Journal of Finance 57, 19972043.

Beck, T., A. Demirguc-Kunt, and R. Levine (2000). A New Database on Financial Development and Structure. World Bank Economic Review September, 597-605.

Beck, T., A. Demirguc-Kunt, and R. Levine (2006). Bank concentration, competition, and crises: First results. Journal of Banking \& Finance 30, 1581-1603.

Boyer, M. M. and D. Filion (2007). Common and fundamental factors in stock returns of Canadian oil and gas companies. Energy Economics 29(3), 428-453.

Carrieri, F., V. Errunza, and S. Sarkissian (2004). Industry Risk and Market Integration. Management Science 50, 207-221.

Carrieri, F. and B. Majerbi (2006). The pricing of exchange risk in emerging stock markets. Journal of International Business Studies 37, 372-391. 
Chen, N.-F., R. Roll, and S. Ross (1986). Economic Forces and the Stock Market. Journal of Business 59, 383-327.

De Santis, G. and B. Gerard (1998). How big is the premium for currency risk? Journal of Financial Economics 49, 375-412.

Doran, J. and E. Ronn (2008). Computing the Market Price of Volatility Risk in the Energy Commodity Markets. Journal of Banking and Finance 32, 2541-2552.

Driesprong, G., B. Jacobsen, and B. Maat (2008). Striking Oil: Another Puzzle. Journal of Financial Economics 89, 307-327.

Dumas, B. and B. Solnik (1995). The world price of exchange rate risk. Journal of Finance 50, $445-477$.

Durham, G. (2003). Likelihood-Based Specification Analysis of Continuous-Time Models of the Short-Term Interest Rate. Journal of Financial Economics 70, 463-487.

Durnev, A. and S. Guriev (2007). The Resource Curse: A Corporate Transparency Channel. CEPR Discussion Papers 6547.

Errunza, V. and E. Losq (1985). International asset pricing under mild segmentation: Theory and test. Journal of Finance 40, 105-124.

Faff, R. and T. Brailsford (1999). Oil price risk and the Australian stock market. Journal of Energy Finance and Development 4, 69-87.

Ferson, W. and C. Harvey (1994a). An Exploratory Investigation of the Fundamental Determinants of National Equity Market Returns. In J. Frankel (Ed.), The Internationalization of Equity Markets. University of Chicago Press.

Ferson, W. and C. Harvey (1994b). Sources of risk and expected returns in global equity markets. Journal of Banking and Finance 18, 1625-1665. 
Gallant, A. R. and G. Tauchen (1998). Reprojecting Partially Observed Systems with Application to Interest Rate Diffusions. Journal of the American Statistical Association 93, 10-24.

Hamilton, J. (1983). Oil and the Macroeconomy since World War II. Journal of Political Economy 91, 228-248.

Hammoudeh, S. and H. Li (2004). The Impact of the Asian Crisis on the Behavior of US and International Petroleum Prices. Energy Economics 26(1), 135-160.

Hodrick, R. (1981). International Asset Pricing with Time-Varying Risk Premia. Journal of International Economics 11, 573-587.

Huang, R., R. Masulis, and H. Stoll (1996). Energy Shocks and Financial Markets. Journal of Futures Markets 16, 1-27.

Jones, C. and G. Kaul (1996). Oil and stock markets. Journal of Finance 51, 463-491.

Jones, D., P. Leiby, and I. Paik (2004). Oil price shocks and the macroeconomy: What has been learned since 1986. The Energy Journal 7, 51-68.

Karolyi, A. and R. Stulz (2003). Are financial assets priced locally or globally? In M. H. D. Constantinides and R. Stulz (Eds.), Handbook of the Economics of Finance. North-Holland, Amsterdam.

Kaufman, D., A. Kraay, and P. Zoido-Lobatn (1999). Aggregating Governance Indicators. World Bank Policy Research Working Paper 2195.

La Porta, R., F. Lopez-de Silanes, A. Shleifer, and R. Vishny (1998). Law and Finance. Journal of Political Economy 106, 1113-1155.

Morck, R., B. Yeung, and W. Yu (2000). The Information Content of Stock Markets: Why Do Emerging Markets Have Synchronous Stock Price Movements? Journal of Financial Economics 58, 215-260. 
Mork, K. (1997). Oil and the Macroeconomy when prices go up and down: An extension of Hamilton's Results. Journal of Political Economy 3, 740-744.

Mork, K., O. Olsen, and H. Mysen (1994). Macroeconomic Responses to Oil Price Increases and Decreases in Seven OECD Countries. Energy Journal 15(4), 19-36.

Nandha, M. and R. Faff (2008). Does oil move equity prices? A global view. Energy Economics 30, 986-997.

Sadorsky, P. (2001). Risk Factors in Stock Returns of Canadian Oil and Gas Companies. Energy Economics 23, 17-28.

Solnik, B. (1974). The international pricing of risk: An empirical investigation of the world capital market structure. Journal of Finance 29, 365-378.

Solnik, B. (1993). The performance of international asset allocation strategies using conditioning information. Journal of Empirical Finance 1, 33-55.

Stulz, R. (1981). A Model of International Asset Pricing. Journal of Financial Economics 9, $383-406$. 


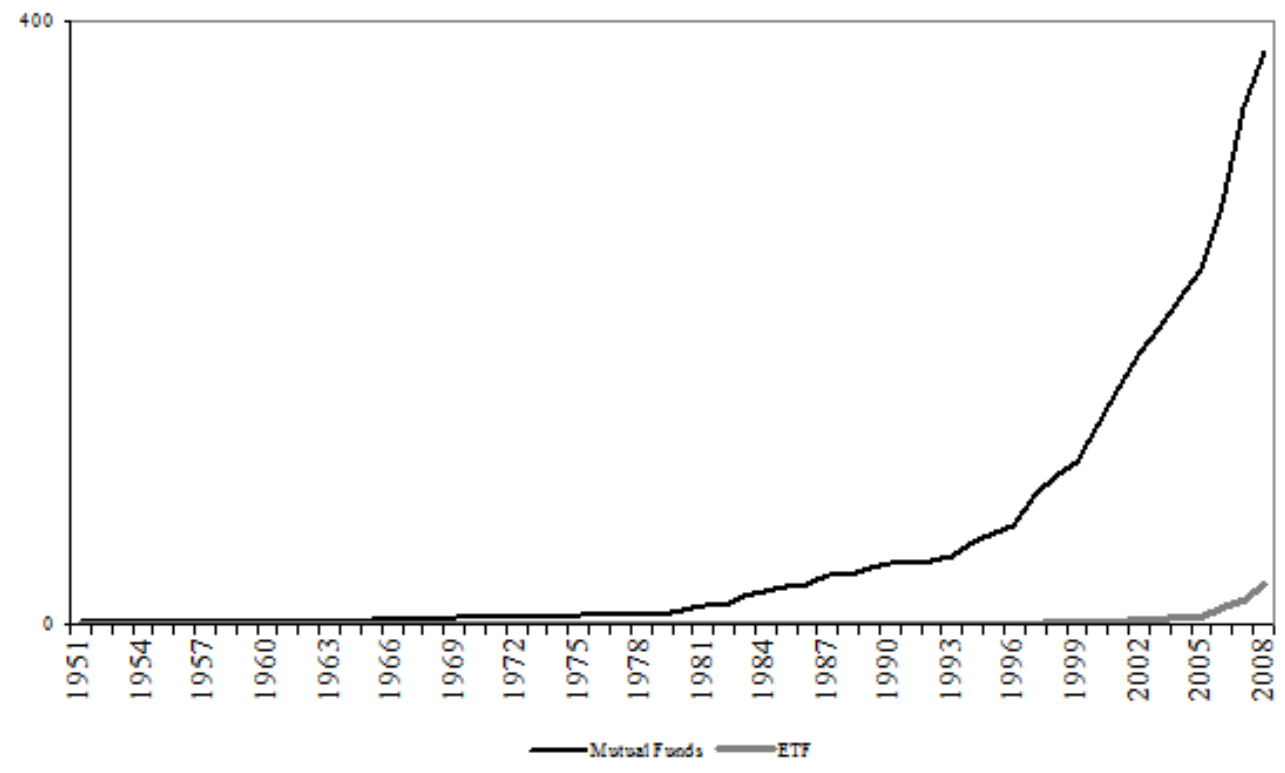

Figure 1. Number of Mutual Funds and Exchange Traded Funds that invest in Oil \& Gas Industry (FTSE Classification). Source: LIPPER. 

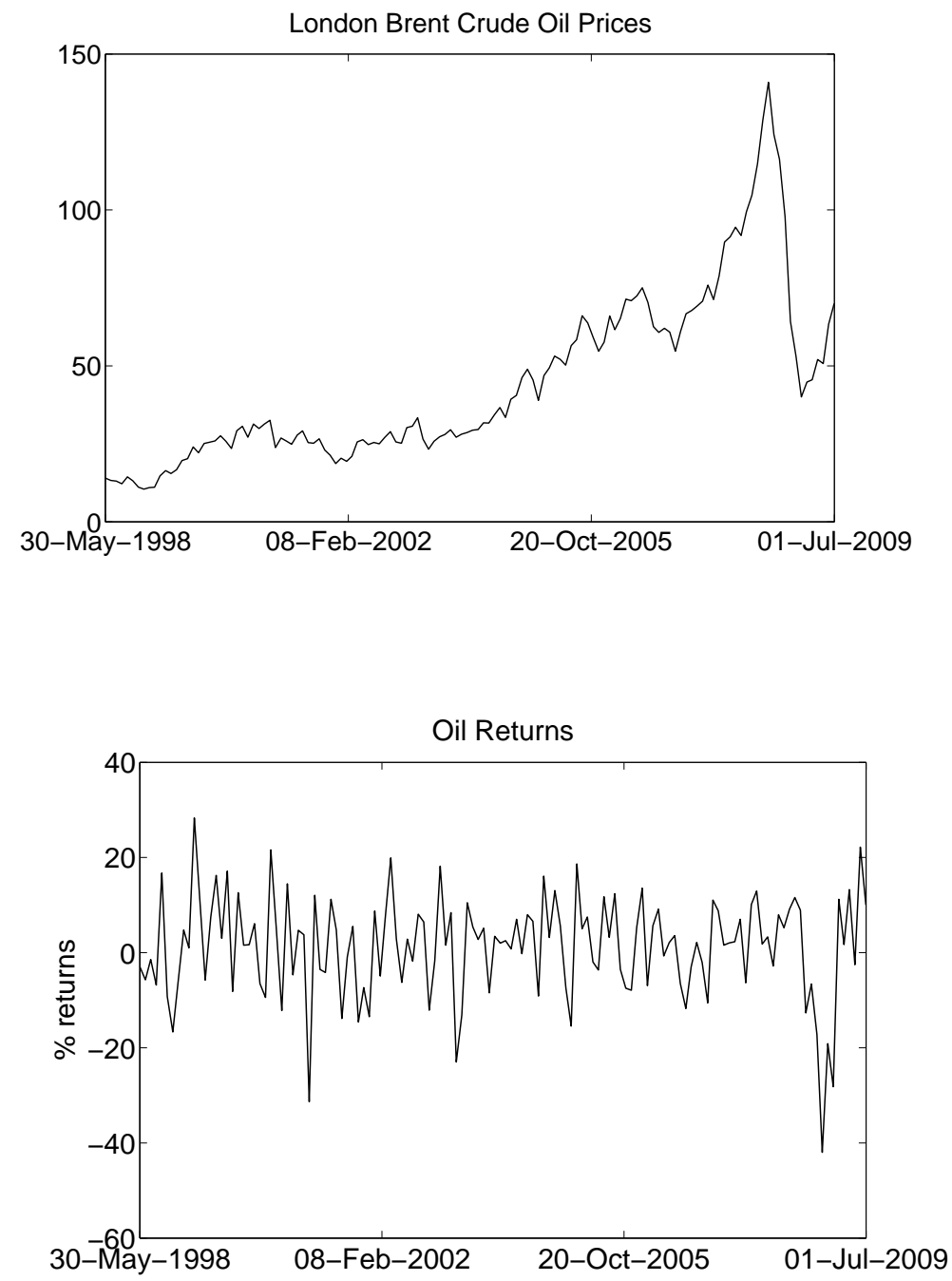

Figure 2. Oil price (first panel) and oil returns in percentage (second panel). 
Table I

\section{Oil and Gas Industry Returns - Summary Statistics}

This table reports the summary statistics of the oil and gas industry monthly returns by country (Level 2 of ICB Classification). The sample period ranges from 1998:05 to 2009:06. By column, we report the mean, the standard deviation (SD), the kurtosis, the skewness, the Jarque-Bera test statistics and their p-value. The returns are the first differences of the logarithm of prices in percentage.

\begin{tabular}{lcccccc}
\hline \multicolumn{1}{c}{ Country } & Mean & SD & Kurtosis & Skewness & Jarque-Bera & P-value \\
\hline Argentina & -0.884 & 11.798 & 7.154 & 0.346 & 94.068 & 0.000 \\
Australia & 0.833 & 9.266 & 4.964 & -0.879 & 36.832 & 0.000 \\
Austria & 0.387 & 10.661 & 5.690 & -1.061 & 62.450 & 0.000 \\
Belgium & 1.022 & 8.299 & 4.407 & -0.121 & 10.364 & 0.006 \\
Brazil & 1.572 & 13.677 & 4.729 & -0.626 & 23.909 & 0.000 \\
Canada & 0.606 & 8.364 & 4.690 & -0.599 & 22.478 & 0.000 \\
Chile & 0.477 & 7.423 & 5.437 & -0.472 & 35.880 & 0.000 \\
China & 0.553 & 13.707 & 6.833 & 0.687 & 88.059 & 0.000 \\
Czech Rep. & 0.714 & 10.386 & 5.368 & -0.640 & 38.174 & 0.000 \\
Denmark & 1.880 & 16.648 & 5.375 & -0.988 & 50.732 & 0.000 \\
France & 0.169 & 6.971 & 4.621 & -0.286 & 15.240 & 0.000 \\
Greece & -0.163 & 10.923 & 5.869 & 0.223 & 44.276 & 0.000 \\
Hong Kong & 0.406 & 12.672 & 4.094 & -0.137 & 6.362 & 0.042 \\
Hungary & 0.227 & 12.266 & 5.342 & -0.940 & 47.865 & 0.000 \\
India & 0.370 & 11.926 & 5.638 & -0.409 & 40.082 & 0.000 \\
Ireland & -0.078 & 13.869 & 4.802 & -0.655 & 26.090 & 0.000 \\
Israel & 0.568 & 10.249 & 4.046 & 0.000 & 5.426 & 0.066 \\
Italy & 0.126 & 6.790 & 4.045 & -0.658 & 14.887 & 0.001 \\
Japan & 0.147 & 8.689 & 2.931 & -0.212 & 1.052 & 0.591 \\
Malaysia & 0.184 & 9.196 & 8.689 & -0.512 & 178.295 & 0.000 \\
Netherlands & -0.042 & 8.747 & 8.131 & -1.345 & 179.615 & 0.000 \\
New Zealand & 1.317 & 9.475 & 3.885 & -0.477 & 8.791 & 0.012 \\
Norway & 0.190 & 9.309 & 5.347 & -0.937 & 47.895 & 0.000 \\
Philippines & -0.716 & 14.345 & 4.350 & 0.336 & 11.690 & 0.003 \\
Poland & 0.620 & 10.547 & 3.854 & -0.264 & 5.073 & 0.079 \\
Romania & -1.367 & 14.127 & 6.519 & -1.001 & 87.263 & 0.000 \\
Singapore & 0.728 & 15.136 & 12.518 & -0.806 & 500.347 & 0.000 \\
South Africa & 0.705 & 10.826 & 4.803 & -0.823 & 31.546 & 0.000 \\
Spain & -0.058 & 7.535 & 7.979 & -1.552 & 184.455 & 0.000 \\
Sri Lanka & -0.091 & 9.190 & 5.102 & 0.286 & 24.719 & 0.000 \\
Thailand & 0.657 & 12.395 & 4.893 & -0.036 & 18.517 & 0.000 \\
Turkey & -0.724 & 16.336 & 4.297 & -0.450 & 12.914 & 0.002 \\
UK & -0.020 & 6.773 & 3.455 & -0.088 & 1.076 & 0.584 \\
US & 0.168 & 6.289 & 3.550 & -0.162 & 1.951 & 0.377 \\
\hline & & & & & & \\
\hline
\end{tabular}


Table II

\section{Summary Statistics of Independent Variables}

This table reports the summary statistics of the independent variables. Explanatory variables are the world market return (WORLD), the country market return (LOCAL), the oil price return (OIL), currency variations against the US dollar (CURRENCY) and volatility of oil price (VOL_OIL). The sample period ranges from 1998:05 to 2009:06. By column, we have the mean, the standard deviation (SD), kurtosis, skewness, the Jarque-Bera test statistics and their p-value.

\begin{tabular}{lcccccc}
\hline Country & Mean & SD & Kurtosis & Skewness & Jarque-Bera & P-value \\
\hline WORLD & -0.229 & 5.211 & 5.930 & -1.115 & 72.205 & 0.000 \\
\hline LOCAL & & & & & & \\
Argentina & -0.925 & 9.867 & 4.610 & -0.673 & 23.164 & 0.000 \\
Australia & 0.167 & 6.596 & 6.298 & -1.102 & 83.844 & 0.000 \\
Austria & 0.002 & 7.413 & 13.639 & -2.224 & 716.094 & 0.000 \\
Belgium & -0.351 & 6.762 & 12.368 & -1.956 & 554.454 & 0.000 \\
Brazil & 0.451 & 12.218 & 4.523 & -0.786 & 25.332 & 0.000 \\
Canada & 0.190 & 6.587 & 7.010 & -1.199 & 116.534 & 0.000 \\
Chile & 0.288 & 6.608 & 6.252 & -1.004 & 77.718 & 0.000 \\
China & 0.951 & 11.003 & 4.732 & 0.218 & 16.446 & 0.000 \\
Czech Rep. & 0.952 & 8.717 & 5.452 & -1.019 & 54.066 & 0.000 \\
Denmark & 0.094 & 6.469 & 8.280 & -1.385 & 190.394 & 0.000 \\
France & -0.161 & 6.307 & 4.916 & -0.905 & 36.845 & 0.000 \\
Greece & -0.275 & 9.073 & 5.910 & -0.997 & 66.177 & 0.000 \\
Hong Kong & 0.121 & 7.391 & 3.879 & -0.009 & 3.770 & 0.152 \\
Hungary & -0.147 & 10.576 & 8.849 & -1.617 & 239.609 & 0.000 \\
India & 0.685 & 10.385 & 5.306 & -0.702 & 38.448 & 0.000 \\
Ireland & -0.647 & 7.088 & 7.603 & -1.307 & 149.853 & 0.000 \\
Israel & 0.246 & 7.262 & 4.191 & -0.801 & 21.130 & 0.000 \\
Italy & -0.428 & 6.684 & 5.369 & -0.630 & 37.905 & 0.000 \\
Japan & -0.241 & 5.689 & 2.692 & -0.072 & 0.790 & 0.674 \\
Malaysia & 0.132 & 8.902 & 8.304 & 0.436 & 153.962 & 0.000 \\
Netherlands & -0.533 & 7.068 & 10.842 & -1.983 & 415.196 & 0.000 \\
New Zealand & -0.136 & 6.491 & 4.083 & -0.718 & 17.106 & 0.000 \\
Norway & 0.006 & 8.698 & 8.528 & -1.661 & 223.154 & 0.000 \\
Philippines & -0.297 & 8.847 & 7.293 & -0.208 & 98.718 & 0.000 \\
Poland & -0.129 & 10.652 & 5.545 & -1.099 & 60.205 & 0.000 \\
Romania & -0.529 & 14.519 & 4.825 & -0.690 & 27.562 & 0.000 \\
Singapore & 0.157 & 7.738 & 5.718 & -0.509 & 44.354 & 0.000 \\
South Africa & 0.111 & 9.766 & 7.224 & -1.447 & 140.350 & 0.000 \\
Spain & -0.117 & 6.416 & 5.772 & -1.004 & 62.276 & 0.000 \\
Sri Lanka & -0.131 & 8.346 & 4.122 & 0.244 & 7.580 & 0.023 \\
Thailand & 0.060 & 11.495 & 4.568 & -0.428 & 16.570 & 0.000 \\
Turkey & -0.078 & 16.421 & 4.505 & -0.414 & 15.289 & 0.000 \\
UK & -0.482 & 5.161 & 7.095 & -0.738 & 100.762 & 0.000 \\
US & -0.401 & 4.915 & 4.473 & -0.835 & 26.264 & 0.000 \\
\hline & & & & & & \\
\hline
\end{tabular}


Table II: continued

\begin{tabular}{lcccccc}
\hline \multicolumn{1}{c}{ Country } & Mean & SD & Kurtosis & Skewness & Jarque-Bera & P-value \\
\hline OIL & 1.178 & 10.830 & 4.579 & -0.712 & 23.803 & 0.000 \\
\hline VOL_OIL & 9.916 & 4.024 & 4.992 & 1.197 & 51.819 & 0.000 \\
\hline CURRENCY & & & & & & \\
Argentina & -0.996 & 6.274 & 50.502 & -6.356 & 13086.000 & 0.000 \\
Australia & 0.161 & 3.744 & 5.265 & -0.738 & 38.596 & 0.000 \\
Austria & 0.190 & 3.035 & 4.336 & 0.069 & 9.132 & 0.010 \\
Belgium & 0.190 & 3.030 & 4.340 & 0.062 & 9.163 & 0.010 \\
Brazil & -0.402 & 6.977 & 27.616 & -3.538 & 3544.500 & 0.000 \\
Canada & 0.155 & 2.553 & 6.968 & -0.590 & 90.976 & 0.000 \\
Chile & -0.122 & 3.337 & 10.822 & -1.605 & 383.945 & 0.000 \\
China & 0.144 & 0.363 & 11.208 & 2.570 & 505.281 & 0.000 \\
Czech Rep. & 0.431 & 3.889 & 4.034 & -0.505 & 10.872 & 0.004 \\
Denmark & 0.190 & 3.008 & 4.328 & 0.049 & 8.970 & 0.011 \\
France & 0.189 & 3.024 & 4.349 & 0.052 & 9.265 & 0.010 \\
Greece & 0.192 & 3.053 & 4.244 & 0.010 & 7.784 & 0.020 \\
Hong Kong & 0.000 & 0.155 & 12.796 & 1.447 & 560.902 & 0.000 \\
Hungary & 0.062 & 4.028 & 8.639 & -1.404 & 212.548 & 0.000 \\
India & -0.137 & 1.620 & 6.853 & -0.421 & 82.412 & 0.000 \\
Ireland & 0.178 & 3.034 & 4.311 & 0.061 & 8.762 & 0.013 \\
Israel & -0.045 & 2.594 & 5.215 & -0.690 & 35.913 & 0.000 \\
Italy & 0.187 & 3.066 & 4.345 & 0.131 & 9.521 & 0.009 \\
Japan & 0.240 & 3.128 & 7.280 & 0.886 & 114.287 & 0.000 \\
Malaysia & 0.045 & 1.479 & 20.724 & 1.197 & 1724.800 & 0.000 \\
Netherlands & 0.189 & 3.035 & 4.339 & 0.073 & 9.182 & 0.010 \\
New Zealand & 0.115 & 3.930 & 4.637 & -0.306 & 15.777 & 0.000 \\
Norway & 0.111 & 3.163 & 4.358 & -0.352 & 12.040 & 0.002 \\
Philippines & -0.135 & 2.320 & 7.474 & -0.748 & 118.509 & 0.000 \\
Poland & 0.055 & 3.934 & 5.575 & -1.057 & 59.060 & 0.000 \\
Romania & -0.956 & 3.672 & 8.137 & -1.058 & 164.937 & 0.000 \\
Singapore & 0.067 & 1.672 & 4.516 & -0.177 & 12.413 & 0.002 \\
South Africa & -0.316 & 5.289 & 3.571 & -0.465 & 6.216 & 0.045 \\
Spain & 0.188 & 3.025 & 4.346 & 0.053 & 9.227 & 0.010 \\
Sri Lanka & -0.445 & 1.495 & 10.721 & -0.766 & 332.017 & 0.000 \\
Thailand & 0.093 & 2.436 & 4.650 & -0.141 & 14.396 & 0.001 \\
Turkey & -1.360 & 5.462 & 13.054 & -1.947 & 625.578 & 0.000 \\
UK & -0.011 & 2.523 & 4.894 & -0.292 & 20.389 & 0.000 \\
\hline & & & & & & \\
\hline
\end{tabular}




\section{Table III}

\section{Correlation among Independent Variables}

This table reports the correlation among variables. Explanatory variables are the world market return (WORLD), the country market return (LOCAL), the oil price return (OIL), currency variations against the US dollar (CURRENCY) and volatility of oil price (VOL_OIL). The sample period ranges from 1998:05 to 2009:06.

\begin{tabular}{lccccc}
\hline & WORLD & LOCAL & OIL & CURRENCY & VOL_OIL \\
\hline WORLD & 1.00 & 0.66 & 0.24 & 0.33 & -0.14 \\
LOCAL & 0.66 & 1.00 & 0.21 & 0.52 & -0.09 \\
OIL & 0.24 & 0.21 & 1.00 & 0.12 & -0.14 \\
CURRENCY & 0.33 & 0.52 & 0.12 & 1.00 & -0.11 \\
VOL_OIL & -0.14 & -0.09 & -0.14 & -0.11 & 1.00 \\
\hline
\end{tabular}


Table IV

\section{Oil and Gas Industry Returns}

This table reports the results of the regressions (2) and (3) from 1998:05 to 2009:06. The dependent variable is the monthly excess returns of the oil and gas industry indexes in US dollars. Explanatory variables include the world market return (WORLD), the country market return (LOCAL), the oil price return (OIL), currency variations against the US dollar (CURRENCY) and volatility of oil price (VOL_OIL). $t$-statistics robust to heteroscedasticity are in parentheses.

\begin{tabular}{|c|c|c|c|c|c|}
\hline & \multicolumn{5}{|c|}{ Panel A: Fixed Effects } \\
\hline & $(1)$ & $(2)$ & (3) & (4) & (5) \\
\hline WORLD & $\begin{array}{r}\mathbf{1 . 0 7 0} \\
(29.789)\end{array}$ & $\begin{array}{r}0.037 \\
(1.059)\end{array}$ & & & \\
\hline LOCAL & & $\begin{array}{r}\mathbf{0 . 9 2 2} \\
(40.453)\end{array}$ & $\begin{array}{r}\mathbf{0 . 8 8 4} \\
(42.672)\end{array}$ & $\begin{array}{r}\mathbf{0 . 9 0 6} \\
(53.543)\end{array}$ & $\begin{array}{r}\mathbf{0 . 8 8 5} \\
(42.680)\end{array}$ \\
\hline OIL & & & $\begin{array}{r}\mathbf{0 . 1 2 6} \\
(10.358)\end{array}$ & $\begin{array}{r}\mathbf{0 . 1 3 0} \\
(10.856)\end{array}$ & $\begin{array}{r}\mathbf{0 . 1 3 0} \\
(10.856)\end{array}$ \\
\hline CURRENCY & & & $\begin{array}{r}\mathbf{0 . 0 9 8} \\
(2.309)\end{array}$ & & $\begin{array}{r}\mathbf{0 . 1 0 7} \\
(2.523)\end{array}$ \\
\hline VOL_OIL & & & & $\begin{array}{r}\mathbf{0 . 0 7 4} \\
(2.624)\end{array}$ & $\begin{array}{r}\mathbf{0 . 0 8 0} \\
(2.831)\end{array}$ \\
\hline Constant & $\begin{array}{r}0.553 \\
(3.918)\end{array}$ & $\begin{array}{r}0.355 \\
(3.270)\end{array}$ & $\begin{array}{r}0.198 \\
(1.808)\end{array}$ & $\begin{array}{r}-0.542 \\
(-1.915)\end{array}$ & $\begin{array}{r}-0.602 \\
(-2.114)\end{array}$ \\
\hline Observations & 4556 & 4556 & 4556 & 4556 & 4556 \\
\hline Number of countries & 34 & 34 & 34 & 34 & 34 \\
\hline R-squared & 0.253 & 0.558 & 0.573 & 0.573 & 0.574 \\
\hline & (1) & $\begin{array}{r}\text { Panel } \\
(2)\end{array}$ & $\begin{array}{r}\text { : Random } \\
\text { (3) }\end{array}$ & $\begin{array}{l}\text { Effects } \\
(4)\end{array}$ & (5) \\
\hline WORLD & $\begin{array}{r}\mathbf{1 . 0 7 0} \\
(29.929)\end{array}$ & $\begin{array}{r}0.038 \\
(1.070)\end{array}$ & & & \\
\hline LOCAL & & $\begin{array}{r}\mathbf{0 . 9 2 2} \\
(40.407)\end{array}$ & $\begin{array}{r}\mathbf{0 . 8 8 2} \\
(42.487)\end{array}$ & $\begin{array}{r}\mathbf{0 . 9 0 6} \\
(53.582)\end{array}$ & $\begin{array}{r}\mathbf{0 . 8 8 3} \\
(42.493)\end{array}$ \\
\hline OIL & & & $\begin{array}{r}\mathbf{0 . 1 2 6} \\
(10.390)\end{array}$ & $\begin{array}{r}\mathbf{0 . 1 3 0} \\
(10.886)\end{array}$ & $\begin{array}{r}\mathbf{0 . 1 3 0} \\
(10.889)\end{array}$ \\
\hline CURRENCY & & & $\begin{array}{r}\mathbf{0 . 1 0 8} \\
(2.543)\end{array}$ & & $\begin{array}{r}\mathbf{0 . 1 1 7} \\
(2.754)\end{array}$ \\
\hline VOL_OIL & & & & $\begin{array}{r}\mathbf{0 . 0 7 4} \\
(2.629)\end{array}$ & $\begin{array}{r}\mathbf{0 . 0 8 1} \\
(2.856)\end{array}$ \\
\hline Constant & $\begin{array}{r}0.553 \\
(3.922) \\
\end{array}$ & $\begin{array}{r}0.355 \\
(3.272)\end{array}$ & $\begin{array}{r}0.198 \\
(1.812) \\
\end{array}$ & $\begin{array}{r}-0.542 \\
(-1.919) \\
\end{array}$ & $\begin{array}{r}-0.608 \\
(-2.138) \\
\end{array}$ \\
\hline Observations & 4556 & 4556 & 4556 & 4556 & 4556 \\
\hline Number of countries & 34 & 34 & 34 & 34 & 34 \\
\hline R-squared & 0.252 & 0.557 & 0.573 & 0.572 & 0.573 \\
\hline
\end{tabular}


Table V

\section{Oil and Gas Industry Returns: Developed Countries vs. Emerging Markets}

This table reports panel regression estimations (Equations (2) and (3)) from 1998:05 to 2009:06. Panel A reports results for developed countries and Panel B for emerging markets. The dependent variable is the monthly excess returns of the oil and gas industry indexes in US dollars. Explanatory variables include the country market return (LOCAL), the oil price return (OIL), currency variations against the US dollar (CURRENCY) and volatility of oil price (VOL_OIL). $t$-statistics robust to heteroscedasticity are in parentheses.

\begin{tabular}{|c|c|c|c|c|c|c|}
\hline & \multicolumn{6}{|c|}{ Panel A: Developed Countries } \\
\hline & \multicolumn{3}{|c|}{ A.1. Fixed Effects } & \multicolumn{3}{|c|}{ A.2. Random Effects } \\
\hline \multirow{2}{*}{$\overline{\text { LOCAL }}$} & 0.919 & 0.931 & 0.922 & 0.919 & 0.931 & 0.922 \\
\hline & $(24.826)$ & $(29.472)$ & $(24.996)$ & $(24.983)$ & $(29.627)$ & $(25.157)$ \\
\hline \multirow[t]{2}{*}{ OIL } & 0.172 & 0.177 & 0.176 & 0.172 & 0.177 & 0.176 \\
\hline & $(9.872)$ & $(10.362)$ & $(10.332)$ & $(9.867)$ & $(10.358)$ & $(10.329)$ \\
\hline \multirow[t]{2}{*}{ CURRENCY } & 0.034 & & 0.042 & 0.034 & & 0.042 \\
\hline & $(0.517)$ & & $(0.635)$ & $(0.512)$ & & $(0.631)$ \\
\hline \multirow[t]{2}{*}{ VOL_OIL } & & 0.090 & 0.091 & & 0.090 & 0.091 \\
\hline & & $(2.228)$ & $(2.256)$ & & $(2.235)$ & $(2.262)$ \\
\hline \multirow[t]{2}{*}{ Constant } & 0.368 & -0.520 & -0.543 & 0.369 & -0.520 & -0.543 \\
\hline & $(2.374)$ & $(-1.281)$ & $(-1.332)$ & $(2.373)$ & $(-1.287)$ & $(-1.336)$ \\
\hline Observations & 2412 & 2412 & 2412 & 2412 & 2412 & 2412 \\
\hline Number of countries & 18 & 18 & 18 & 18 & 18 & 18 \\
\hline \multirow[t]{4}{*}{ R-squared } & 0.476 & 0.477 & 0.477 & 0.475 & 0.477 & 0.477 \\
\hline & \multicolumn{6}{|c|}{ Panel B: Emerging Markets } \\
\hline & \multicolumn{3}{|c|}{ B.1.Fixed Effects } & \multicolumn{3}{|c|}{ B.2. Random Effects } \\
\hline & (1) & (2) & (3) & (4) & (5) & (6) \\
\hline \multirow[t]{2}{*}{ LOCAL } & 0.871 & 0.897 & 0.870 & 0.870 & 0.898 & 0.869 \\
\hline & $(34.599)$ & $(44.702)$ & $(34.546)$ & $(34.526)$ & $(44.787)$ & $(34.468)$ \\
\hline \multirow[t]{2}{*}{ OIL } & 0.072 & 0.074 & 0.075 & 0.072 & 0.074 & 0.075 \\
\hline & $(4.478)$ & $(4.665)$ & $(4.725)$ & $(4.500)$ & $(4.679)$ & $(4.745)$ \\
\hline \multirow[t]{2}{*}{ CURRENCY } & 0.131 & & 0.140 & 0.137 & & 0.146 \\
\hline & $(2.455)$ & & $(2.631)$ & $(2.563)$ & & $(2.734)$ \\
\hline \multirow[t]{2}{*}{ VOL_OIL } & & 0.059 & 0.071 & & 0.059 & 0.072 \\
\hline & & $(1.517)$ & $(1.814)$ & & $(1.522)$ & $(1.833)$ \\
\hline \multirow[t]{2}{*}{ Constant } & 0.039 & -0.589 & -0.668 & 0.041 & -0.589 & -0.672 \\
\hline & $(0.260)$ & $(-1.506)$ & $(-1.700)$ & $(0.272)$ & $(-1.511)$ & $(-1.713)$ \\
\hline Observations & 2144 & 2144 & 2144 & 2144 & 2144 & 2144 \\
\hline Number of countries & 16 & 16 & 16 & 16 & 16 & 16 \\
\hline R-squared & 0.658 & 0.657 & 0.659 & 0.658 & 0.657 & 0.658 \\
\hline
\end{tabular}




\section{Table VI}

\section{Oil and Gas Industry Returns: Asymmetric Effects of Oil Price Changes}

This table reports panel regression estimations (Equation (4)). The sample ranges from 1998:05 to 2008:05. Panel A: Reports results for fixed effects models and Panel B for random effects models. The dependent variable is the monthly excess returns of the oil and gas industry indexes in US dollars. Explanatory variables include the country market return (LOCAL), positive variations of oil price returns (OIL_P), negative variations of oil price returns (OIL_N), currency variations against the US dollar (CURRENCY) and volatility of oil price (VOL_OIL). $t$-statistics robust to heteroscedasticity are in parentheses.

\begin{tabular}{lrrrrrr}
\hline & \multicolumn{3}{c}{ Panel A: Fixed Effects } & \multicolumn{3}{r}{ Panel B: Random Effects } \\
& $(1)$ & $(2)$ & $(3)$ & $(4)$ & $(5)$ & $(6)$ \\
\hline & & & & & & \\
LOCAL & $\mathbf{0 . 8 8 7}$ & $\mathbf{0 . 9 0 7}$ & $\mathbf{0 . 8 8 7}$ & $\mathbf{0 . 8 8 5}$ & $\mathbf{0 . 9 0 7}$ & $\mathbf{0 . 8 8 5}$ \\
& $(43.054)$ & $(53.789)$ & $(43.041)$ & $(42.878)$ & $(53.841)$ & $(42.862)$ \\
OIL_P & $\mathbf{0 . 1 8 1}$ & $\mathbf{0 . 1 7 3}$ & $\mathbf{0 . 1 6 9}$ & $\mathbf{0 . 1 8 1}$ & $\mathbf{0 . 1 7 3}$ & $\mathbf{0 . 1 6 8}$ \\
& $(7.949)$ & $(7.097)$ & $(6.940)$ & $(7.918)$ & $(7.063)$ & $(6.899)$ \\
OIL_N & $\mathbf{0 . 0 7 8}$ & $\mathbf{0 . 0 9 0}$ & $\mathbf{0 . 0 9 3}$ & $\mathbf{0 . 0 7 8}$ & $\mathbf{0 . 0 9 0}$ & $\mathbf{0 . 0 9 4}$ \\
& $(3.280)$ & $(3.565)$ & $(3.704)$ & $(3.309)$ & $(3.592)$ & $(3.746)$ \\
CURRENCY & $\mathbf{0 . 0 9 4}$ & & $\mathbf{0 . 1 0 1}$ & $\mathbf{0 . 1 0 4}$ & & $\mathbf{0 . 1 1 1}$ \\
& $(2.212)$ & & $(2.375)$ & $(2.449)$ & & $(2.612)$ \\
VOL_OIL & & 0.042 & 0.051 & & 0.042 & 0.052 \\
& & $(1.401)$ & $(1.688)$ & & $(1.401)$ & $(1.717)$ \\
Constant & -0.246 & -0.582 & -0.635 & -0.244 & -0.582 & -0.641 \\
& $(-1.320)$ & $(-2.032)$ & $(-2.206)$ & $(-1.314)$ & $(-2.037)$ & $(-2.229)$ \\
\hline Observations & 4556 & 4556 & 4556 & 4556 & 4556 & 4556 \\
Number of countries & 34 & 34 & 34 & 34 & 34 & 34 \\
R-squared & 0.574 & 0.574 & 0.575 & 0.573 & 0.573 & 0.574 \\
\hline$H_{0}: \beta_{O I L P}=\beta_{O I L N}$ & 6.610 & 3.630 & 2.990 & 6.600 & 3.640 & 2.940 \\
P-value & 0.010 & 0.057 & 0.084 & 0.010 & 0.056 & 0.087 \\
\hline$H_{0}: \beta_{O I L P}=0$ and $\beta_{O I L N}=0$ & 64.360 & 64.120 & 63.650 & 128.260 & 127.950 & 127.120 \\
P-value & 0.000 & 0.000 & 0.000 & 0.000 & 0.000 & 0.000 \\
\hline
\end{tabular}


Table VII

\section{Oil and Gas Industry Returns: Subperiods}

This table reports panel regression estimations (Equations (2) and (3)) for two subperiods: 1998-2001 (Panel A) and 2002-2009 (Panel B), using random effects specifications. The dependent variable is the monthly excess returns of the oil and gas industry indexes in US dollars. Explanatory variables include the country market return (LOCAL), the oil price return (OIL), currency variations against the US dollar (CURRENCY) and volatility of oil price (VOL_OIL). $t$-statistics robust to heteroscedasticity are in parentheses.

\begin{tabular}{|c|c|c|c|c|c|c|}
\hline & \multicolumn{3}{|c|}{ Panel A: 1998-2001 } & \multicolumn{3}{|c|}{ Panel B: 2002-2009 } \\
\hline & (1) & $(2)$ & $(3)$ & (4) & $(5)$ & (6) \\
\hline \multirow[t]{2}{*}{ LOCAL } & 0.814 & 0.822 & 0.798 & 0.941 & 0.954 & 0.945 \\
\hline & $(27.357)$ & $(29.990)$ & $(26.136)$ & $(32.013)$ & $(43.280)$ & $(32.082)$ \\
\hline \multirow[t]{2}{*}{ OIL } & 0.105 & 0.095 & 0.095 & 0.131 & 0.139 & 0.139 \\
\hline & $(5.416)$ & $(4.847)$ & $(4.892)$ & $(8.601)$ & $(9.488)$ & $(9.486)$ \\
\hline \multirow[t]{2}{*}{ CURRENCY } & 0.154 & & 0.172 & 0.036 & & 0.039 \\
\hline & $(2.216)$ & & $(2.512)$ & $(0.598)$ & & $(0.661)$ \\
\hline \multirow[t]{2}{*}{$V O L \_O I L$} & & 0.275 & 0.287 & & 0.090 & 0.091 \\
\hline & & $(3.709)$ & $(3.872)$ & & $(2.826)$ & $(2.846)$ \\
\hline \multirow[t]{2}{*}{ Constant } & -0.131 & -3.310 & -3.365 & 0.326 & -0.518 & -0.531 \\
\hline & $(-0.513)$ & $(-3.613)$ & $(-3.665)$ & $(2.582)$ & $(-1.727)$ & $(-1.765)$ \\
\hline Observations & 1496 & 1496 & 1496 & 3060 & 3060 & 3060 \\
\hline Number of countries & 34 & 34 & 34 & 34 & 34 & 34 \\
\hline R-squared & 0.511 & 0.514 & 0.516 & 0.609 & 0.610 & 0.610 \\
\hline
\end{tabular}


Table VIII

\section{Explaining Oil and Gas Industry Sensitivities}

This table reports the results of regressing the sensitivities of Oil\&Gas Industry on a set of country variables. Explanatory variables are SMT/GDP, the weight of stock market trade over GDP (SMT/GDP) from the World Bank (Beck et al. (2000)), CIFAR an index from the Center for Financial Analysis and Research, which assess information on comprehensiveness and quality the of companies' balance sheets and income statements. GOOD_GOV is the sum of three indexes from La Porta et al. (1998) (1) government corruption, (2) the risk of expropriation of private property by the government, and (3) the risk of government repudiation of the contracts. KKZ_INDEX is a measure the overall level of institutional development. It is composed of the following items: voice and accountability, government effectiveness, political instability, regulatory quality, rule of law and control of corruption (Kaufman et al. (1999)). The $t$-statistics are in parentheses and are computed using White-heteroscedasticity consistent standard errors.

\begin{tabular}{|c|c|c|c|c|c|c|c|}
\hline & \multicolumn{7}{|c|}{ Panel A: $\beta_{O I L, i}$ are computed using LOCAL and OIL } \\
\hline & (1) & (2) & (3) & (4) & (5) & (6) & (7) \\
\hline \multirow[t]{2}{*}{ SMT/GDP } & 0.132 & & & & 0.091 & 0.126 & 0.101 \\
\hline & $(3.552)$ & & & & $(2.576)$ & $(3.140)$ & $(2.517)$ \\
\hline \multirow[t]{2}{*}{ CIFAR } & & 0.004 & & & & & -0.001 \\
\hline & & $(1.870)$ & & & & & $(-0.549)$ \\
\hline \multirow[t]{2}{*}{ GOOD_GOV } & & & 0.013 & & 0.010 & & 0.009 \\
\hline & & & $(3.584)$ & & $(2.741)$ & & $(2.134)$ \\
\hline \multirow[t]{2}{*}{ KKZ Index } & & & & 0.038 & & 0.012 & \\
\hline & & & & $(1.455)$ & & $(0.498)$ & \\
\hline \multirow[t]{2}{*}{ Constant } & 0.073 & -0.121 & -0.182 & 0.101 & -0.148 & 0.065 & -0.053 \\
\hline & $(3.000)$ & $(-0.839)$ & $(-1.983)$ & $(3.313)$ & $(-1.754)$ & $(2.233)$ & $(-0.388)$ \\
\hline Adj. R-Squared & 0.260 & 0.088 & 0.297 & 0.033 & 0.419 & 0.243 & 0.344 \\
\hline \multirow[t]{3}{*}{ Observations } & 34 & 27 & 29 & 34 & 29 & 34 & 27 \\
\hline & $\overline{\text { Pane }}$ & $\overline{\mathrm{B}}: \beta_{O I L, i}$ & are compu & ed using & $\overline{\mathrm{CAL}}, \mathrm{OII}$ & and $\mathrm{CU}$ & RENCY \\
\hline & (1) & (2) & (3) & (4) & (5) & (6) & (7) \\
\hline \multirow[t]{2}{*}{ SMT/GDP } & 0.136 & & & & 0.093 & 0.129 & 0.102 \\
\hline & $(5.149)$ & & & & $(3.555)$ & $(3.221)$ & $(3.848)$ \\
\hline \multirow[t]{2}{*}{ CIFAR } & & 0.004 & & & & & -0.001 \\
\hline & & (1.918) & & & & & $(-0.591)$ \\
\hline \multirow[t]{2}{*}{ GOOD_GOV } & & & 0.013 & & 0.010 & & 0.009 \\
\hline & & & $(3.589)$ & & $(2.702)$ & & (1.896) \\
\hline \multirow[t]{2}{*}{ KKZ Index } & & & & 0.040 & & 0.013 & \\
\hline & & & & $(1.507)$ & & $(0.537)$ & \\
\hline \multirow[t]{2}{*}{ Constant } & 0.072 & -0.125 & -0.181 & 0.100 & -0.146 & 0.064 & -0.055 \\
\hline & $(2.999)$ & $(-0.872)$ & $(-1.971)$ & $(3.271)$ & $(-1.621)$ & $(2.181)$ & $(-0.498)$ \\
\hline Adj. R-Squared & 0.272 & 0.093 & 0.298 & 0.037 & 0.424 & 0.255 & 0.349 \\
\hline Observations & 34 & 27 & 29 & 34 & 34 & 29 & 27 \\
\hline
\end{tabular}


Table IX

Oil and Gas Industry - NYMEX Oil Future Returns

This table reports panel regression estimations (Equation (2)) of the excess returns of the oil and gas industry indexes for 34 countries from May 1997 to July 2008. The dependent variable is the monthly excess returns of the oil and gas industry indexes in U.S. dollars. Explanatory variables include the world market return (WORLD), the country market return (LOCAL), the NYMEX oil price future returns (OIL), currency variations against the US dollar (CURRENCY) and volatility of oil price (VOL_OIL).t-statistics robust to heteroscedasticity are in parentheses.

\begin{tabular}{|c|c|c|c|}
\hline & \multicolumn{3}{|c|}{ Panel A: Fixed Effects } \\
\hline & $(1)$ & $(2)$ & $(3)$ \\
\hline \multirow[t]{2}{*}{ LOCAL } & 0.888 & 0.907 & 0.887 \\
\hline & $(42.648)$ & $(53.242)$ & $(42.588)$ \\
\hline \multirow[t]{2}{*}{ OIL } & 0.113 & 0.116 & 0.116 \\
\hline & $(9.103)$ & $(9.478)$ & $(9.424)$ \\
\hline \multirow[t]{2}{*}{ CURRENCY } & 0.092 & & 0.100 \\
\hline & $(2.152)$ & & $(2.344)$ \\
\hline \multirow[t]{2}{*}{ VOL_OIL } & & 0.071 & 0.077 \\
\hline & & $(2.442)$ & $(2.615)$ \\
\hline \multirow[t]{2}{*}{ Constant } & 0.218 & -0.496 & -0.546 \\
\hline & $(1.991)$ & $(-1.705)$ & $(-1.871)$ \\
\hline Observations & 4556 & 4556 & 4556 \\
\hline Number of countries & 34 & 34 & 34 \\
\hline \multirow[t]{3}{*}{ R-squared } & 0.571 & 0.571 & 0.571 \\
\hline & Panel & : Random & Effects \\
\hline & $(1)$ & $(2)$ & $(3)$ \\
\hline \multirow[t]{2}{*}{ LOCAL } & 0.885 & 0.907 & 0.885 \\
\hline & $(42.462)$ & $(53.309)$ & $(42.405)$ \\
\hline \multirow[t]{2}{*}{ OIL } & 0.113 & 0.116 & 0.116 \\
\hline & $(9.116)$ & $(9.491)$ & $(9.436)$ \\
\hline \multirow[t]{2}{*}{ CURRENCY } & 0.102 & & 0.110 \\
\hline & $(2.391)$ & & $(2.580)$ \\
\hline \multirow[t]{2}{*}{ VOL_OIL } & & 0.071 & 0.077 \\
\hline & & $(2.443)$ & $(2.634)$ \\
\hline \multirow[t]{2}{*}{ Constant } & 0.218 & -0.496 & -0.552 \\
\hline & $(1.996)$ & $(-1.707)$ & $(-1.891)$ \\
\hline Observations & 4556 & 4556 & 4556 \\
\hline Number of countries & 34 & 34 & 34 \\
\hline R-squared & 0.570 & 0.570 & 0.571 \\
\hline
\end{tabular}


Table X

\section{Oil and Gas Industry Returns- Panel Data with time dummies}

This table reports panel regression estimations (Equation (2)) of the excess returns of the oil and gas industry indexes for 34 countries for two subperiods: 1998-2001 (Panel A) and 2002-2009 (Panel B). The dependent variable is the monthly excess returns of the oil and gas industry indexes in U.S. dollars. Explanatory variables include the world market return (WORLD), the country market return (LOCAL), the oil price return (OIL), currency variations against the US dollar (CURRENCY) and volatility of oil price (VOL_OIL). t-statistics robust to heteroscedasticity are in parentheses.

\begin{tabular}{lrrrrrr}
\hline & \multicolumn{3}{c}{ Panel A: Fixed Effects } & \multicolumn{3}{c}{ Panel B: Random Effects } \\
& $(1)$ & $(2)$ & $(3)$ & $(4)$ & $(5)$ & $(6)$ \\
\hline \multirow{2}{*}{ LOCAL } & & & & & & \\
& $\mathbf{0 . 8 6 5}$ & $\mathbf{0 . 8 7 5}$ & $\mathbf{0 . 8 6 5}$ & 0.862 & 0.875 & 0.862 \\
OIL & $(31.101)$ & $(36.944)$ & $(31.101)$ & $(30.930)$ & $(36.893)$ & $(30.930)$ \\
& 0.130 & $\mathbf{0 . 1 5 4}$ & $\mathbf{0 . 1 5 6}$ & 0.129 & $\mathbf{0 . 1 5 5}$ & $\mathbf{0 . 1 5 6}$ \\
CURRENCY & $(1.794)$ & $(2.819)$ & $(2.842)$ & $(1.809)$ & $(2.852)$ & $(2.878)$ \\
& 0.054 & & 0.054 & 0.069 & & 0.069 \\
VOL OIL & $(1.067)$ & & $(1.067)$ & $(1.360)$ & & $(1.360)$ \\
& & 0.070 & 0.085 & & 0.070 & 0.089 \\
Constant & & $(0.639)$ & $(0.773)$ & & $(0.655)$ & $(0.827)$ \\
& -0.584 & -1.120 & -1.264 & -0.591 & -1.120 & -1.302 \\
& $(-0.478)$ & $(-0.567)$ & $(-0.641)$ & $(-0.502)$ & $(-0.587)$ & $(-0.683)$ \\
\hline Observations & 4556 & 4556 & 4556 & 4556 & 4556 & 4556 \\
Number of countries & 34 & 34 & 34 & 34 & 34 & 34 \\
R-squared & 0.608 & 0.608 & 0.608 & 0.607 & 0.607 & 0.607 \\
\hline Time Dummies & Yes & Yes & Yes & Yes & Yes & Yes \\
\hline
\end{tabular}


Table XI

Oil and Gas Industry - Weekly Returns

This table reports panel regression estimations (Equations (2) and (3)) of the excess returns of the oil and gas industry indexes from 1998:05 to 2009:6. The dependent variable is the weekly excess returns of the oil and gas industry indexes in US dollars. Explanatory variables include the world market return (WORLD), the country market return (LOCAL), the oil price return (OIL), currency variations against the US dollar (CURRENCY) and volatility of oil price (VOL_OIL). t-statistics corrected for time level clustering are in parentheses.

\begin{tabular}{|c|c|c|c|c|c|}
\hline & \multicolumn{5}{|c|}{ Panel A: Fixed Effects } \\
\hline & (1) & (2) & (3) & (4) & (5) \\
\hline \multirow[t]{2}{*}{ WORLD } & 0.902 & 0.043 & & & \\
\hline & $(48.436)$ & $(2.532)$ & & & \\
\hline \multirow{2}{*}{ LOCAL } & & 0.911 & 0.886 & 0.906 & 0.886 \\
\hline & & $(70.404)$ & $(75.169)$ & $(88.277)$ & $(75.091)$ \\
\hline \multirow{2}{*}{ OIL } & & & 0.100 & 0.102 & 0.101 \\
\hline & & & $(16.427)$ & $(16.925)$ & $(16.773)$ \\
\hline \multirow{2}{*}{ CURRENCY } & & & 0.108 & & 0.109 \\
\hline & & & $(4.305)$ & & $(4.346)$ \\
\hline \multirow{2}{*}{ VOL OIL } & & & & 0.012 & 0.017 \\
\hline & & & & $(0.781)$ & $(1.077)$ \\
\hline \multirow[t]{2}{*}{ Constant } & 0.117 & 0.079 & 0.050 & -0.004 & -0.028 \\
\hline & $(3.466)$ & $(2.983)$ & $(1.862)$ & $(0.063)$ & $(0.387)$ \\
\hline Observations & 19822 & 19822 & 19822 & 19822 & 19822 \\
\hline Number of countries & 34 & 34 & 34 & 34 & 34 \\
\hline \multirow[t]{3}{*}{ R-squared } & 0.188 & 0.494 & 0.503 & 0.503 & 0.503 \\
\hline & & nel B: R & ndom Eff & ects Effe & \\
\hline & (1) & $(2)$ & (3) & $(4)$ & $(5)$ \\
\hline WORLD & $\begin{array}{r}\mathbf{0 . 9 0 2} \\
(48.511)\end{array}$ & $\begin{array}{r}\mathbf{0 . 0 4 3} \\
(2.542)\end{array}$ & & & \\
\hline \multirow[t]{2}{*}{ LOCAL } & & 0.911 & 0.886 & 0.906 & 0.886 \\
\hline & & $(70.535)$ & $(75.400)$ & $(88.412)$ & $(75.324)$ \\
\hline \multirow[t]{2}{*}{ OIL } & & & 0.100 & 0.102 & 0.101 \\
\hline & & & $(16.444)$ & $(16.948)$ & $(16.790)$ \\
\hline \multirow[t]{2}{*}{ CURRENCY } & & & 0.109 & & 0.110 \\
\hline & & & $(4.409)$ & & $(4.450)$ \\
\hline \multirow[t]{2}{*}{ VOL OIL } & & & & 0.012 & 0.017 \\
\hline & & & & $(0.782)$ & $(1.081)$ \\
\hline \multirow[t]{2}{*}{ Constant } & 0.117 & 0.079 & 0.050 & -0.004 & -0.028 \\
\hline & $(3.467)$ & $(2.9839$ & $(1.861)$ & $(0.063)$ & $(0.390)$ \\
\hline Observations & 19822 & 19822 & 19822 & 19822 & 19822 \\
\hline Number of countries & 34 & 34 & 34 & 34 & 34 \\
\hline R-squared & 0.188 & 0.494 & 0.503 & 0.502 & 0.503 \\
\hline
\end{tabular}


A. Appendix - Country Variables 
Table A.1

\section{Country Variables}

This table reports values for country variables. CIF AR is an accounting standards index from the Center for Financial Analysis and Research. The maximum value of the index is 90 and the minimum is 0 . GOOD_GOV is the sum of three indexes from La Porta et al. (1998): (1) government corruption, (2) the risk of expropriation of private property by the government, and (3) the risk of government repudiation of the contracts. Higher values indicate that there is more respect for private property. KKZ_INDEX is an index developed by Kaufman et al. (1999) that measures the quality of institutions. It is composed of the following items: voice and accountability, government effectiveness, political instability, regulatory quality, rule of law and control of corruption. Higher values are associated with better quality of institutions. Stock market activity is proxied by the weight of stock market trade over GDP (SMT/GDP). Data are from (see Beck et al., 2000).

\begin{tabular}{|c|c|c|c|c|}
\hline & CIFAR & KKZ Index & GOOD_GOV & SMT/GDP \\
\hline Argentina & 45.00 & -0.58 & 16.84 & 0.04 \\
\hline Australia & 75.00 & 1.65 & 26.50 & 0.71 \\
\hline Austria & 54.00 & 1.64 & 27.86 & 0.04 \\
\hline Belgium & 61.00 & 1.44 & 27.93 & 0.12 \\
\hline Brazil & 54.00 & 0.02 & 20.24 & 0.12 \\
\hline Canada & 74.00 & 1.65 & 28.63 & 0.56 \\
\hline Chile & 52.00 & 1.28 & 19.60 & 0.09 \\
\hline China & - & -0.34 & - & 0.34 \\
\hline Czech Republic & - & 0.81 & - & 0.10 \\
\hline Denmark & 62.00 & 1.83 & 28.98 & 0.32 \\
\hline France & 69.00 & 1.29 & 27.89 & 0.57 \\
\hline Greece & 55.00 & 0.86 & 21.01 & 0.22 \\
\hline Hong Kong & 69.00 & 1.16 & 25.63 & 2.09 \\
\hline Hungary & - & 0.96 & - & 0.10 \\
\hline India & 57.00 & -0.18 & 18.44 & 0.48 \\
\hline Ireland & - & 1.56 & 27.15 & 0.30 \\
\hline Israel & 64.00 & 0.56 & 24.12 & 0.37 \\
\hline Italy & 62.00 & 0.93 & 24.65 & 0.45 \\
\hline Japan & 65.00 & 1.14 & 27.88 & 0.53 \\
\hline Malaysia & 76.00 & 0.45 & 22.76 & 0.49 \\
\hline Netherlands & 64.00 & 1.83 & 29.33 & 0.91 \\
\hline New Zealand & 70.00 & 1.80 & 28.98 & 0.14 \\
\hline Norway & 74.00 & 1.74 & 29.59 & 0.32 \\
\hline Philippines & 65.00 & -0.22 & 12.94 & 0.03 \\
\hline Poland & - & 0.69 & - & 0.04 \\
\hline Romania & - & 0.01 & - & 0.01 \\
\hline Singapore & 78.00 & 1.67 & 26.38 & 0.96 \\
\hline South Africa & 70.00 & 0.38 & 23.07 & 0.60 \\
\hline Spain & 64.00 & 1.27 & 25.30 & 1.12 \\
\hline Sri Lanka & - & -0.12 & 16.30 & 0.04 \\
\hline Thailand & 64.00 & 0.25 & 20.17 & 0.66 \\
\hline Turkey & 51.00 & -0.26 & 18.13 & 0.41 \\
\hline United Kingdom & 78.00 & 1.64 & 28.44 & 1.20 \\
\hline United States & 71.00 & 1.39 & 27.61 & 1.42 \\
\hline Average & 64.56 & 0.89 & 24.22 & 0.47 \\
\hline St.Dev. & 8.86 & 0.75 & 4.66 & 0.47 \\
\hline Number Observations & 27 & 34 & 29 & 34 \\
\hline
\end{tabular}

